Article

\title{
From the 8-Hour Day to the 40-Hour Week: Legitimization Discourses of Labour Legislation between the Wars in France and Belgium
}

\author{
Sabine Rudischhauser \\ Centre de Recherches Mondes Modernes et Contemporains, Université Libre de Bruxelles, 1050 Brussels, Belgium; \\ E-Mail: rs@cmb.hu-berlin.de
}

Submitted: 23 September 2016 | Accepted: 9 November 2016 | Published: 15 March 2017

\begin{abstract}
In the interwar period both France and Belgium passed legislation reducing the number of working hours and established a hybrid regulatory regime lending a certain degree of official authority to collective agreements. The paper analyses discourses by scholars who, as experts, were close to the political elites, and who tried to legitimize this kind of co-regulation by pointing out the inefficiency of state intervention and the epistemic authority of non-state actors. Stressing the output dimension of legitimacy and the improved quality of legal norms, these discourses had a technocratic tendency and ultimately argued in favour of a shift of power from the legislative to the administrative branch of government.
\end{abstract}

\section{Keywords}

Belgium; France; Georges Scelle; Henri Velge; labour legislation; Paul Grunebaum-Ballin; public-private regulation

\section{Issue}

This article is part of the issue "Legitimization of Private and Public Regulation: Past and Present", edited by Klaus Dieter Wolf (Peace Research Institute Frankfurt, Germany), Peter Collin (Max Planck Institute for European Legal History, Germany) and Melanie Coni-Zimmer (Peace Research Institute Frankfurt, Germany).

(C) 2017 by the author; licensee Cogitatio (Lisbon, Portugal). This article is licensed under a Creative Commons Attribution 4.0 International License (CC BY).

\section{Introduction}

This paper addresses a sector-specific regulatory structure, namely legislation reducing the number of working hours per day or per week and, in order to achieve this aim, referring to collective agreements. The laws discussed in this paper make the application of the law dependent on the existence and contents of collective agreements, or leave the concretization of the law to collective agreements, or give them power to derogate from the law. This wide-spread form of public-private regulation emerged right after the end of the First World War and is a dominant feature of labour law in France and Belgium to the present day. Taking up the questions outlined in the introduction, this article will discuss how such hybrids were legitimized in the interwar period.

The problem of legitimization of public-private regulation can be resumed, in this specific case, briefly as follows: Parliamentary democracy acknowledges parliament as the only body representing the will of the na- tion. Decisions are made by majority; laws apply to everyone. Norm-setting through administrative rulings is only legitimate (and legal) as far as the law, passed by parliament, permits. When workers' collective action was legalized in France and Belgium, trade unions demanded to fix the rules of the trade, negotiating wages and working conditions with employers and their associations. At the outbreak of the war, such collective agreements were widely accepted as legitimate, but their legal status was still under debate. In Belgium, collective agreements were not considered legally binding, representing no more than a 'gentlemen's agreement'. In France, but also in Germany and other countries, they were considered to be contracts, binding only upon the parties of the contract. The French law on collective agreements of 25 March 1919 confirmed this doctrine. Consequently, the idea that trade unions and employers' associations could set norms binding on every member of the trade, their agreements enjoying, within this professional space, the same universal authority as a law, was highly controver- 
sial. Practical experience had, however, shown that collective agreements in many cases could only work and be enforced, if every employer and worker, whether member of a union or not, was bound to respect the wages and working conditions laid down in the collective agreement. Making the parties to collective agreements participate in generating and implementing laws on the reduction of working hours was thus an experiment combining the universality of rules set by the state with the negotiation of private contracts.

At first glance, it might seem obvious that such a new, experimental form of public-private regulation of labour on a national scale would stand in need of legitimization. However, when analysing the debates following the laws on the 8-hour day in the after war period, and those surrounding the laws on the 40-hour week in 1936, we find an apparently much higher need for legitimization of regulation on the French side, concerning the 1919 law, and a much more intense debate on the Belgian side in the thirties. Our question of how this type of public-private regulation was legitimized, thus leads us to ask in which specific historical contexts a need for legitimization was perceived, and by whom.

As different ways to combine legislative, administrative, and contractual regulation were developed in France (Fridenson, 2004) and Belgium, we expect to observe different patterns of legitimization. We must, however, take into account that the discourses we analyse do not always reflect the specific regulatory arrangement made by the law in question. In fact, authors refer to these laws, but follow a logic of their own and may pursue political aims only loosely connected to the laws they are pretending to legitimate. Because of the possible gap between the actual public policy implemented and the discourse, it will be necessary to give a detailed presentation of the laws and administrative practises before analysing legitimization discourses.

The first section of the paper will give a brief account of the historical context of the laws on the 8-hour day, present the specific regulatory arrangements in France and Belgium, and discuss which criteria and sources of legitimacy permitted the legislation on the reduction of working hours to pass parliament. The second section will analyse the dominant French discourses on the cooperation between the state and organized capital and labour in producing and implementing labour law. These discourses strongly favour output related arguments to legitimate this cooperation, vaunting it as a first step towards a technocratic form of norm-setting in France. The third section will, again, briefly present the historical context and the content of the laws on the 40-hour week, before showing how Belgian discourses legitimizing the labour laws of 1936 went on to promote larger corporatist projects of state reform. The paper thus focuses on two points in time: the immediate post-war period, and 1936, when both countries knew a period of social unrest and intense debate of labour legislation, the French legislation exerting a strong influence on the Belgian labour movement.

\section{The Law on the 8-Hour Day}

In both countries, labour legislation before 1914 met with many obstacles. Bills aiming at introducing shorter working days or compulsory social insurance failed in parliament or were delayed for years; more than once, court rulings rendered labour laws inoperable. This lack of support demonstrates that, while workers and their organizations were clamouring for laws reducing working time, state intervention into the working conditions of adult men, which would have limited the 'liberté du travail' of employers and workers, was not considered legitimate by a considerable part of the political and academic elite. If 'legitimacy is indicated by actor's compliance with...a set of social obligations', (Johnson, Dowd, \& Ridgeway, 2006 , p. 55), labour legislation's legitimacy was low in the eyes of French employers, too. Lawmakers and administrators struggled to devise regulations universal in scope, but sufficiently flexible to adapt to the needs of various industries, without on the other hand being too complex to allow for verification by state inspectors. Labour legislation was criticized in France for being either too schematic or for creating an all-encroaching bureaucracy, when specific regulations adapted to specific socio-economic situations had to be enforced. In a famous text published in 1901, Emile Durkheim (1901) described this dilemma of state regulation: general and uniform labour laws must be inefficient, but detailed regulation for each branch of industry would enhance the tendency towards an 'état hypertrophié', an excessively developed state. Therefore, he suggested creating a modern version of the ancient corporations of masters and journeymen, able to regulate the different branches of industry, and to devolve part of the state's norm - setting power to them, allowing them to produce 'la loi de la profession'. Durkheim considered new corporations, created by law, necessary because of what he and many of his contemporaries perceived as the shortcomings of French trade unions: they did not organize the majority of workers and were thus not deemed 'representative'. Consequently, trade unions and employers' associations lacked democratic legitimacy for setting norms binding upon all employers and workers of a given branch of industry (Rudischhauser, 2016, pp. 810-814).

During the war, however, the French state called upon leaders of trade unions and employers' associations to sit upon a great number of tripartite commissions and bodies set up by the state, where they 'represented' workers' and employers' interests in dealing with social and economic problems, from unemployment to women's work to wage-setting. The state thus acknowledged trade unions and employers' associations and declared their collaboration to be indispensable in organizing the war economy. Through this collaboration with the government, the organizations gained a new legitimacy. Trade unions in France, as in other allied countries, now claimed a role in the post-war national and international order, too. At the International Trade Union 
Conference in Leeds in 1916, delegates from the trade unions of Belgium, Italy, France, and the UK drew up a program of workers' rights to be incorporated in the future peace treaty. This program included a reduction of working hours and the establishment of an international labour office. When peace negotiations opened in Paris in January 1919, a commission on international labour legislation was set up to prepare the relevant articles of the treaty, presided over by a trade unionist. Its final report on 4 March recommended the adoption of the 8-hour day. Manifestly, labour legislation, especially the reduction of working hours, had become a matter for international treaties as well as for trade unionists and employers' organizations to decide upon. They were no longer merely consulted. The Versailles Treaty laid the foundations of the International Labour Organization (ILO), whose constitution rested on the principle of tripartism: delegates of national governments (two for each government) and of a nation's 'most representative' trade unions and employers' associations (one delegate each) were to discuss and decide together. The ILO represented a new normative order based on the collaboration of delegates from national governments, capital, and labour for the purpose of norm-setting (Rodgers, Lee, Swepston, \& Van Daele, 2009). Legislation introducing the 8-hour day was part of the Versailles Treaty (Art. 427) and the object of the Washington convention, its ratification a chief aim of the ILO.

These developments put the French government under intense pressure. The 8-hour day had been accepted as 'the standard to be aimed at' (Ramm, 1986, p. 107) by the allies and had already been proclaimed in Germany. Not least because of the hopes and emotions raised by the Bolshevist Revolution, the French government was afraid of revolutionary strikes and street protests, and thus it tried to immediately appease some of the workers' expectations. Looking for a quick solution, it decided against normal parliamentary procedure, which in the past had often delayed labour legislation for years on end. Implicating trade unions' and employers' representatives in the making of the law was a must, if the political aim of this legislation, social peace, was to be reached. The government therefore asked the Commission Interministerielle des Traités Internationaux du Travail to discuss the 8-hour day, one of the many 'mixed' commissions where state and non-state actors collaborated (Oualid \& Picquenard, 1928, p. 321). Here, Charles Picquenard, a top-level public servant at the Ministry of Labour, proposed a two tier system: The principle of the 8-hour day was to be proclaimed by law, the details and modes of application were to be determined by administrative rulings based on collective agreements. The Conseil d'Etat, who was to establish the administrative rulings, would not be bound to reproduce the content of the collective agreement in question, but would only have to take it into consideration.

Picquenard's system was essential to make the employers' representatives accept the 8-hour day. The Com- mission adopted the text, containing only four articles, on 7 April, the government introduced the bill on 8 April, and the Chamber (the Lower House of Parliament) adopted it on 17 April and the Senate (the Upper House) on 23 April, both times unanimously. This consensus and rapidity cannot be explained by the pressure of the workers' movements alone. More important was the fact that delegates of workers' and employers' organizations, considered as legitimate representatives, had already agreed on this solution. The logic of the 8-hour day law-gaining legitimacy for state regulation by integrating those directly concerned into the norm-setting process-was already at work in the making of the law.

Given the context, it might seem plausible to argue that this type of public-private regulation relied mainly on input legitimacy enhanced through the participation of stake-holders in decision-making processes (Scharpf, 1998). However, a closer look at the debates in parliament raises doubts about whether this was the argument that permitted the law to pass. In March 1919 the Senate, the upper house of the French parliament, refused to accept an amendment to the law on collective agreements. This amendment would have given the prefects, the government appointed heads of the regional administrations, power to extend a collective agreement to all employers and workers concerned. The Senate was not prepared to let a prefect turn a collective agreement into a kind of administrative ruling, commanding universal authority. Only four weeks later, the bill on the 8-hour day was accepted, which enabled the Conseil d'Etat to give legal and universal force to a collective agreement by transferring its contents into an administrative ruling.

This change of the Senate's attitude is striking, especially since the rapporteur, speaking in favour of the law, and the main speaker answering, were the same both times. There was no difference as to the qualification and legitimacy of collective agreements and the negotiating parties, on which the 8-hour day law was mostly silent. The difference lay in the nature of the state actor and the scope of his prerogatives. The prefect, being an instrument of the respective government, did not provide guarantees to employers, whereas the Conseil d'Etat, being an independent judiciary body, did. Functioning also as an administrative court, it was credited with defending individual rights like 'liberté du travail' against government interventions. Most importantly, the relation between the exercise of state authority and the authority of the private contract was different. Whereas the prefect would have extended the collective agreement as such, having no power to change its content, the Conseil d'Etat, when drafting the administrative ruling, retained the upper hand, being only obliged to refer to the collective agreement. The legitimacy of the regulatory regime rested on the legitimacy of the Conseil d'Etat, whose source was not democracy, but judicial independence and juridical expertise. The Senators, and especially the powerful industrialists and conservative lawyers who dominated these debates, were firmly re- 
solved to enclose the new form of public-private regulation within the older, established forms of norm-setting, which had guaranteed their influence on the decisionmaking process so far (Rudischhauser, 2016, p. 687f.).

Our argument will become clearer as we consider the Belgian regulatory arrangement. In Belgium, in April 1919 , the government installed joint committees ('Commissions paritaires'), where trade unions and employers' associations were equally represented, calling them 'study commissions' (Commission d'Études pour la Réduction de la Durée du Travail dans les Usines Sidérurgiques; Commission d'Études pour la Réduction de la Durée du Travail dans les Mines, etc.), charged to study ways and means to reduce the length of the working day. In fact, they negotiated collective agreements on working conditions and wages. (Neuville, 1976) The Belgian mode of labour regulation resembled the one practised in Britain: the 8-hour day was at first achieved through (state-sponsored) collective bargaining. When a general law on the 8-hour day was passed on 14 June 1921, most major branches had already reached an agreement, which, as in Britain, was not legally binding but nevertheless widely respected. The law allowed companies to apply for authorization to exceed the limit of 8 hours per day respectively 48 hours per week. Authorization could only be given if a prior agreement had been reached with the trade unions most representative of the workers employed in the company concerned. The law thus implicitly recognized trade unions as the legitimate representatives of workers and collective agreements as valid contracts, although neither trade unions, nor collective agreements had a legal status. The 8-hour day law gave 'de véritables droits à des organisations dépourvus d'existence légale' (Velge, 1934, p. 242). Nevertheless, there was hardly any debate on the legitimacy of this regulatory regime in Belgium. The Belgian arrangement proved profitable for both sides: collective agreements laid the foundations for state regulation, improving its legitimacy, while trade unions and employers' associations gained importance and legitimacy, not least in the eyes of their constituencies, as the growth of membership demonstrates.

The implementation of the French law on the 8hour day provided a stimulus to collective bargaining, but it also put trade unions in a much weaker position than the Belgian law did. At the same time, it sacrificed one of the major advantages of state regulation, namely universality. While the law was supposed to offer the benefit of the 8-hour day to every worker, its application was subject to administrative rulings (règlements d'administration publique), which determined when and how the 8-hour day would come into force in a specific 'profession, industry, trade or professional category'. These rulings were based, as far as possible, on collective agreements, of which only some concerned whole branches of industry, others specific professions. Accordingly, administrative rulings were issued for the metal industries on 9 September 1920, for hair-dressers on $26 \mathrm{Au}$ - gust 1921, for joiners on 31 December 1921, and so on (Pic, 1930, pp. 567, 584). Norm concretization and implementation was a very slow, piecemeal process, depending on successful negotiations. Trade unions and employers' associations could negotiate a choice from a wide variety of legal possibilities, as the working day was supposed to comport 8 hours on average, the average being calculated per week, per month, or per quarter of the year. Besides, temporary as well as permanent derogations could be agreed upon. But in fact, no state action was taken without a collective agreement being signed first. As a result, the last administrative rulings were issued in 1935 (Leray, 1998). Contrary to the Belgian organizations, which gained legitimacy in the course of the implementation, French organizations lost creditability every time the Conseil d'Etat's ruling departed from the original collective agreement. The law on the 8-hour day did not allow trade unions and employers' associations to be the best judges of what arrangement was most appropriate for their specific trade or industry. However, the law did not aim at lending collective agreements additional authority and stability, but rather to help the state out of the dilemma Durkheim had sketched out.

\section{Legitimizing the French Model}

Because the 8-hour day was rushed through parliament, no elaborate legitimization discourses were developed at the time, and the discourses studied here were elaborated ex post. Shortly after the law on the 8-hour day had been passed, two major articles were published in one of the leading French political journals, the Revue Politique et Parlementaire, on the participation of employers' and workers' organizations in the making of laws. Both were written by jurists who were very influential in the public sphere of the 1920s and 1930s, and both presented the 8-hour day law as a model for future labour laws.

Paul Grunebaum-Ballin was a top level public servant and a well-known figure of the left, who had made a brilliant career at the Conseil d'Etat (Thuillier, 2001) and acquired experience in collective bargaining as an arbitrator in labour conflicts in the navy. The application of the 8-hour day to the merchant navy in a special law of 2 August 1919 provided the occasion for his article (Grunebaum-Ballin, 1920). The application of the law, following the same system as the general law on the 8hour day, had been a positive experience for GrunebaumBallin: 'Le nouveau mécanisme fonctionne parfaitement' (1920, p. 46). Both sides had rapidly reached an agreement, assisted by 'technicians', jurists and administrators. The joint committee had been presided over by a conseiller d'Etat, who then wrote the report preparing the administrative ruling. Grunebaum-Ballin praises this procedure as much quicker than parliamentary deliberations, and stresses the "competences" of the participants, their professional (= linked to the branch of industry concerned), juridical, and administrative expertise. In his article, the expertise and 'wisdom' of 
'the technicians of law' appears as at least as important as the expertise of 'the professionals'. To him, the new mode of regulation represents a collaboration between 'the political' and 'the technical' within the joint committees, which he dubs 'commissions techniques législatives'. For the future, he recommended that parliament state the principles and leave all the rest of legal norm-setting to 'l'accord collectif des représentants qualifiés des organisations patronales et ouvrières intéressées, à l'ingéniosité et à la sagesse des gouvernants, des fonctionnaires, des juristes qui prépareront, discuteront et signeront les règlements d'administration publique' (1920, p. 44).

Grunebaum-Ballin was not so much trying to legitimize public-private regulation, as using the law on the 8-hour day to legitimize a reform of the parliamentary system, a constitutional reform. Criticism of parliament was key, and not, as with Durkheim, criticism of bureaucracy or the welfare state. Grunebaum-Ballin relates his very negative experience of parliamentary proceedings, where perfectly well-prepared and carefully drafted projects (in this instance, the Code du travail maritime), approved by everybody concerned, were stuck and could not be discussed and passed. ${ }^{1}$ This is why he advocates the procedure established in the 8-hour day laws as a new, much more efficient method of legislation. To legitimize this new method, he likens the sovereign parliament to the absolute monarchy, abandoning a part of its prerogatives at the beginning of the 1789 revolution. He quotes Saint-Simon and Proudhon, imagining the rule of contract replacing the rule of law, economic forces replacing political authorities, functional categories-agriculture, industry, commerce-replacing classes. Following the theses advanced by Léon Duguit, Grunebaum-Ballin suggests abandoning the notion of the sovereign state, putting the idea of social service, run by public servants, in its place. In doing so, he argues no longer in favour of Proudhon's rule of contract, but in favour of a rule of technicians: Technocracy. GrunebaumBallin's argument implied that lawmaking could be depoliticized, reduced to technical instead of political decisions. As far as he was concerned with the legitimacy of the mode of regulation established through the 8-hour day laws, it rested on the improved quality of legal norms.

A similar pattern of legitimization can be found in the writings of Georges Scelle, a socialist and jurist, better known for his later work on international law. At the time of his article, he taught labour law in Dijon; in 1924, he would become chef de cabinet of the minister of labour, Justin Godart, one of the 'fathers' of the law on the 8hour day in 1919. Scelle's article, as Grunebaum-Ballin's, places the accent on legislative techniques and methods (Scelle, 1920). His starting point is the debate on sources and authors of law, the question of whether law is necessarily a product of parliament. To Scelle, there are other ways of producing law, namely what he calls 'autonomous' law, negotiated between employers and workers. Such a negotiated, contractual law, 'la loi conventionelle, acceptée et non imposée' (Scelle, 1920, p. 29) has a better chance of being obeyed, will be a better informed and more objective law, taking into account all opinions and interests. In later studies, Scelle would call the law on the 8-hour day itself a 'kind of collective agreement', because it had been negotiated and agreed upon between employers' and workers' representatives in a tripartite commission (Scelle, 1927, p. 208). This notion of a 'contractual law' is linked to an idea of industrial democracy, replacing the 'monarchy' of the employer. Scelle thus represents collective agreements as the 'true' labour laws.

Just as Grunebaum-Ballin, Scelle is very critical of parliamentary methods. Laws voted in parliament are always too late, and incompetent. Parliament should therefore only state the general principles and create the framework to facilitate and stimulate collective bargaining, that is, the 'secondary', 'contractual', true labour law. Scelle elaborates this distinction between 'primary' and 'secondary' legislation in his later textbooks on labour law. In his 1927 Précis Élémentaire de Législation Industrielle, Scelle, contrary to Grunebaum-Ballin, does not credit the Conseil d'Etat with a technical competence. He limits its role to a control of legality; its main function is to confer obligatory force to a contractual arrangement that would otherwise be binding only to the members of the contracting organizations. Scelle does not consider the Conseil d'Etat as the guardian of general interest. He glosses over the fact that legally the Conseil d'Etat is not bound to accept the text of the collective agreement and does not mention the instances when the Conseil d'Etat had, in fact, not done so. This distortion of the role of the Conseil d'Etat enables Scelle to present the 8-hour day law as a step 'towards the autonomy of the regulation of labour'.

But this 'autonomous legislation' is legitimated exclusively by its results, its higher quality, due to the competence of workers and employers, and its inherent flexibility. Scelle is convinced that the new legislative technique will make the modification of legal norms easier when economic situations change, assuming that collective bargaining is always quicker than parliamentary procedure (Scelle, 1922, p. 107), which is obviously not true in the case of the 8-hour day. In his argument, 'autonomy' designates only the 'spontaneous' emergence of this kind of law, as opposed to parliamentary law. Nowhere does Scelle mention or reflect upon a right to self-regulation or the existence of an autonomous normative sphere. Consequently, he does not reflect on the legitimacy of the existing trade unions and employers' associations to set norms which will become compulsory even for outsiders. Scelle and Grunebaum-Ballin's central legitimation topoi are expert knowledge and competence, which Grunebaum-Ballin locates with the top administration, especially the Conseil d'Etat, Scelle with the employers' and workers' organizations.

\footnotetext{
${ }^{1}$ Grunebaum-Ballin's real aim was to get 'his' Code du Travail Maritime passed. The corresponding law is reproduced in the annex of his article.
} 
Scelle's distinction between 'primary' and 'secondary' legislation became a kind of official doctrine of the French Ministry of Labour, whose department of labour was continuously under the direction of Charles Picquenard until 1937. Picquenard was proud of the new legislative technique he had invented. In his eyes, the main advantage of the 8-hour day law was that it allowed 'the generalization of collective agreements' (Oualid \& Picquenard, 1928, p. 292), transforming them into norms binding on everybody working within the branch concerned. The 8-hour day law, in his eyes, compensated for the Senate's refusal of the extension of collective agreements. Picquenard considers the new technique as a means of turning employers' and workers' organizations into second degree lawmakers, into 'les auxiliaires professionnels, techniques ou régionaux du législateur parlementaire', a technique which opens 'immense horizons' (Oualid \& Picquenard, 1928, p. 295f.). Speaking of a 'division of labour', he adopts Scelle's formula of a 'collaboration hierarchisée entre le législateur parlementaire et le législateur autonome'.

French jurists of the left, close to or part of the administration, were quite satisfied with this 'autonomy', while corporatists on the right of the political spectrum tended to minimize the importance of this kind of collaboration. Jean Brèthe de la Gressaye, a well-known Catholic corporatist, highlighted the importance of another law, of 29 December 1923, on the weekly day of rest (Brèthe de la Gressaye, 1930, pp. 76-92). It gave the prefect power to order shops to be closed on the day fixed in a corresponding collective agreement. Brèthe considered that this law, contrary to the one on the 8-hour day, gave real regulatory power to the organizations of employers and workers, which they shared with the prefect. Because the prefect could only intervene at their demand and according to the rules fixed in the collective agreement, 'for the first time, the regulatory authority was at the disposal of the professional organizations' (Rivero, 1939, p. 195). But the only argument Brèthe explicitly offered in favour of such a hybrid regulation referred to output: a regulation adapted to the needs of each branch and to local circumstances could only be achieved through the collaboration of the parties concerned.

\section{The 40-Hour Week in Belgium: Cautious Corporatists}

Just as the introduction of the 8-hour day, the reduction of the number of hours worked per week to 40 was justified on social and economic grounds, namely as a means to fight unemployment. From 1931 onward, an international debate on such a reduction of working time engaged legal experts and trade-unionists in Europe, resulting in ILO Convention No. 47 of 1935 (Chatriot, 2004). But only when in 1936 a massive wave of strikes forced a change of policies did parliaments in France and four weeks later in Belgium pass a law on the 40-hour week. The mode of regulation chosen reflected past experiences with the 8-hour day, but also, in the case of Bel- gium, a broad debate on new mechanisms and organizations that would enable employers and workers to regulate the economy and participate in norm-setting.

The French law on the 40-hour week, passed on 21 June 1936, superficially resembles the 8-hour day law. Again, a very laconic text was rushed through parliament in a hurry. Ministerial decrees, one for each branch of the economy, were to determine how the 40-hour week would be introduced. Employers' and workers' organizations had to be consulted, the decrees had to refer to collective agreements, if they existed. But this time, the whole procedure was centralized and organized by the Ministry of Labour, which consulted the employers' and workers' organizations of each branch of the economy and then handed the dossier to the competent section of the Conseil national économique, on whose report it drafted the decree (décrets rendus en conseil des ministres). The legitimacy of the Conseil national économique was based on its representative nature, as only organizations deemed to be 'the most representative' of the branch concerned could designate members to the Conseil national économique (Chatriot, 2002, 2007). But the political nature of the Ministry's decisions was clearly visible. The negotiations within the sections of the Conseil national économique produced the technical advice the ministry was asking for, but did not confer an additional legitimacy to the application of the 40-hour week, which was famously criticized for its 'rigidity' (Chatriot, 2004, p. 84). Its critics did not perceive the law on the 40-hour week as a continuation of the French model of secondary lawmaking, but as a return to state regulation. Consequently, its legitimacy was weak in the eyes of those employers, politicians, and academics, who had always opposed labour legislation. Authors close to these circles, at the same time, praised the flexibility of the Belgian law on the 40-hour week.

This law on the 40-hour week, of 9 July 1936 (Revue du Travail, 1936, pp. 783-784), was to be applied only in industries presenting dangers or health hazards. Consultation of joint committees or trade unions and employers' associations was mandatory. A royal decree could confer legal force to a joint committee's decision (in fact, a collective agreement) and extend it to all employers and workers working in the branch of industry concerned. The same provisions are to be found in the law, passed one day earlier, on paid holidays for workers. The royal decree thus incorporated the content of a collective agreement, transforming it into imperative law, to be controlled and enforced by the state inspection of factories. Contraventions were accordingly penalized. But-perhaps as a precaution-the joint committees were still called study commissions, as in 1919: 'commission d'étude de la réduction de la durée hebdomadaire du travail dans les mines de Houille' etc. (Revue du Travail, 1937, pp. 709-713).

The 1936 Belgian legislation built on the de facto legitimacy and authority of collective agreements (respectively joint committees), and it did not legislate on collec- 
tive agreements as such, nor give a legal status to the existing trade unions and employers' associations. The government did not create the new corporations Durkheim had once demanded, although the creation of 'organisations professionnelles', able to regulate the economy, had been proclaimed official government policy (Velge, 1937, p. 202) in order 'to simplify the government's task of intervention'. 'Organisation professionnelle' was a keyword in the Belgian debates on public-private regulation and enjoyed a vague, but broad appeal in the economic and social crisis of the 1930s. All parts of the political spectrum were calling for an organized or planned economy. 'Organisation professionnelle' came close to representing a kind of consensus, because it appealed to conservatives and liberals hostile to state intervention and bureaucracy, to Catholics inspired by the encyclical Quadragesimo anno, and even to many socialists.

The most elaborate proposals for 'Organisation professionnelle' were made by Henri Velge, professor of law at Leuven University, well-known for his corporatist doctrines and his campaign for the establishment of a Belgian Conseil d'Etat. In an article published in the 'Revue du Travail', the official journal of the Belgian Ministry of Labour, in 1937, Velge defends the 1936 laws as being perfectly constitutional, and he sees the transformation of decisions made by workers and employers' organizations into decrees as a model to be followed and generalized (Velge, 1937). He wants to maintain the prerogatives of the state but turn labour organizations into collaborators of government and parliament. Government should retain the final decision in order to defend the general interest of the nation. But the initiative should rest with the organizations, whose regulations could then be transformed into royal decrees. According to Velge's conception, workers and employers' organizations were not limited to the concretization and application of a law passed in parliament. While the executive was given power to rule by decree, listening to the initiatives and demands of economic organizations, parliament's role was weakened.

Anti-parliamentarism was an important factor in the debates on public-private regulation. The Belgian debate of the 1930s no longer turned around the question of how to pass labour legislation quickly and improve its quality, but aimed at a constitutional reform. In 1937, a study-commission for the reform of the state (Commission d'Études pour la Réforme de l'Etat [CERE]), adopted and generalized Velge's conception: any kind of professional regulation could be turned, by royal decree, into a legal obligation for all employers and workers working in the branch of industry concerned. Anybody concerned could oppose such a move, appealing to a special court, which would decide whether the regulation was contrary to the constitution, the laws, or the general interest (Revue du Travail, 1937, pp. 1854-1868). The Belgian government introduced a bill in 1938, based on Velge's project and the proposals of the CERE. 'Every joint committee...may solicit that a collective agreement be transformed into a professional regulation and extended to all producers, distributers and workers belonging to the same branch of industry, agriculture, or commerce....' (Vleeschauwer, 1950, pp. 83-174). All these proposals included provisions about the legal status of trade unions and employers associations, but also created additional legal bodies on top of the private organizations. The proposals refrained from giving private organizations outright regulatory authority and took a lot of precautions to safeguard the authority of the government.

The same caution pervades the legitimization discourses developed. The main argument was, as it had been in France, quality of output. Legal regulation was denounced as incomplete and faulty, because the government lacked the information and expertise, due to the problems of state intervention in a complex society. The collaboration of actors working in the branch of industry concerned was thus necessary to unburden the state: 'public authorities must discharge themselves of a mission they can no longer fulfil' (Velge, 1942, p. 19). This criticism of state intervention as such added to the widespread criticism of parliament, whose legislation, especially on labour, was shown to be ill-prepared, hasty, and uncoordinated.

But behind this well-established pattern of legitimization, authors like Velge harboured ideas for a new society in which everybody was consciously part of a group, the 'profession'. To develop the 'organisations professionnelles' was consequently a value as such to him. Velge, who knew how highly controversial his vision of a new society was, stayed silent on the nature of the profession (which hardcore corporatists treated as a natural group, like family), and did not give a name to the new organization he was proposing. Although engaged in Catholic politics, he did not once refer to sources of legitimacy like subsidiarity, autonomy, or self-government.

Such general concepts appeared only in the discourses of the 1950s, when both French and Belgian jurists used more audacious terms. In a comprehensive volume on 'organisation professionelle', Robert Vleeschauwer, professor of law at Leuven University, proclaimed subsidiarity as the principle of regulation corresponding to natural law. In France, Paul Durand, in the first volume of his authoritative treatise on labour law, talked about the spontaneous formation of 'professional law', quoting Scelle, Sinzheimer, and Ihering. He still used the established reference to the shortcomings of 'droit étatique', criticized as incomplete and rigid, 'unable to adapt to the divers and changing forms of social life'. But the next sentence acknowledged a claim of non-state actors to self-regulation: 'Every group aspires to exert a regulatory power. Corporative law develops spontaneously, which completes and even corrects the legal rule.' (Durand, 1950, p. 124).

\section{Conclusion}

Legitimization discourses of labour legislation between the wars in France and Belgium had a common point of 
departure: a perceived crisis of state regulation. New hybrid modes of norm-setting in Belgium rested on the experience that trade unions and employers' associations could and would arrive at collective agreements, setting the rules for their respective trade. This mode of regulation was widely considered legitimate, but lacked a legal framework, which may explain why legal scholars hesitated to elaborate on its normative foundations. The construction of this legal framework proved difficult still in 1936/37, although the transformation of collective agreements into administrative rulings no longer met with opposition. While the law on the 8-hour day had bolstered the legitimacy of collective agreements, the proponents of 'organisation professionnelle' in the 1930s were mainly intent on increasing the power of the executive, side-stepping parliament. In France, the law on the 8-hour day had already limited the role of parliament and given considerable power to the administration and the supreme administrative court, the Conseil $d^{\prime} E t a t$. The law established the Conseil d'Etat as the defender of the common interest, free to set aside the will of the concerned workers and employers as expressed in their collective agreement. In 1936, the law on the 40hour week made agreements reached between employers' and workers' representatives within the sections of the Conseil national économique part of a procedure so closely organized and dominated by the government that these agreements could not be represented as free private contracts. The mode of regulation chosen for the concretization of the 40-hour week thus did not gain legitimacy.

Delegitimizing parliament proved to be a key element for legitimizing public-private collaboration in the making and application of labour laws in the interwar period. In both France and Belgium, parliament was regularly depicted as overburdened and incompetent. The discourses analysed in this paper followed the logic of Durkheim's argument, calling for hybrid regulation in order to discharge parliament. The legitimacy of hybrid regulation was thus mainly derived from the needs and shortcomings of the state, and from the epistemic authority of non-state actors. Other sources of legitimacy, like autonomy or self-regulation, were hardly referred to. Only after the Second World War, when trade unions had gained considerable prestige and political weight, was the claim of trade unions to participate in norm-setting recognized as legitimate.

\section{Acknowledgements}

Published with the support of the Belgian University Foundation (Publié avec le concours de la Fondation Universitaire de Belgique).

\section{Conflict of Interests}

The author declares no conflict of interests.

\section{References}

Brèthe de la Gressaye, J. (1930). Le syndicalisme, l'organisation professionnelle et l'Etat. Paris: Librairie du Recueil Sirey.

Chatriot, A. (2002). La démocratie sociale à la française. L'expérience du Conseil national économique, 19241940. Paris: Éditions la Découverte.

Chatriot, A. (2004). Débats internationaux, rupture politique et négociations sociales: Le bond en avant des 40 heures, 1932-1938. In P. Fridenson \& B. Reynaud (Eds.), La France et le temps de travail (1814-2004) (pp. 83-108). Paris: Odile Jacob.

Chatriot, A. (2007). Les apories de la représentation de la société civile. Débats et expériences autour des compositions successives des assemblées consultatives en France au XXe siécle. Revue Française de Droit Constitutionnel, 71, 535-555.

Durand, P. (1950). Traité du droit du travail (Vol. 1). Paris: Dalloz.

Durkheim, E. (1901). De la division du travail social. (2nd ed.). Paris: Alcan.

Fridenson, P. (2004). La multiplicité des processus de réduction de la durée du travail de 1814 à 1932: Négociations, luttes, textes et pratiques. In P. Fridenson \& B. Reynaud (Eds.), La France et le temps de travail (1814-2004) (pp. 55-82). Paris: Odile Jacob.

Grunebaum-Ballin, P. (1920). La participation des organisations professionnelles à l'exercice du pouvoir législatif. Revue Politique et Parlementaire, 102, 42-56.

Johnson, C., Dowd, T. J., \& Ridgeway, C. L. (2006). Legitimacy as social process. Annual Review of Sociology, 32, 53-78.

Leray, I. (1998). La réduction du temps de travail pour tous: La loi du 23 avril 1919 sur les huit heures. In J.-P. Le Crom (Ed.), Deux siécles de droit du travail. L'histoire par les textes (pp. 117-128). Paris: Éditions de l'Atelier.

Neuville, J. (1976). Histoire du mouvement ouvrier en Belgique. L'évolution des relations industrielles (Vol. 5). Bruxelles: Vie Ouvrière.

Oualid, W., \& Picquenard, C. (1928). Salaires et tarifs. Conventions collectives et grèves. La politique du ministère de l'armement et du ministère du travail. Paris: PUF.

Pic, P. (1930). Traité élémentaire de législation industrielle: Les lois ouvrières. Paris: A. Rousseau.

Ramm, T. (1986). Laissez-faire and state protection of workers. In B. Hepple (Ed.), The making of labour law in Europe. A comparative study of nine countries up to 1945 (pp. 73-113). London and New York, NY: Mansell Publishing Ltd.

Revue du Travail. (1936). Loi du 9 juillet 1936 instituant la semaine de quarante heures dans les industries ou sections d'industrie où le travail est effectué dans des conditions insalubres, dangereuses ou pénibles. $R e$ vue du Travail, 783-784. 
Revue du Travail. (1937). Rapport de la commission d'étude de la réduction de la durée hebdomadaire du travail dans les mines de Houille. Plans pour la Reforme de l'Etat. Revue du Travail, 709-713.

Rivero, J. (1939). Le repos hebdomadaire, arrêt du Conseil d'Etat du 23 novembre 1938, note. Droit Social, 1, 194-199.

Rodgers, G., Lee, E., Swepston, L., \& Van Daele, J. (2009). L'OIT et la quête de justice sociale, 1919-2009. Geneve: Bureau International du Travail.

Rudischhauser, S. (2016). Geregelte Verhältnisse. Eine Geschichte des Tarifvertragsrechts in Deutschland und Frankreich, 1890-1918/19. Bonn, Weimar, and Wien: Böhlau Verlag.

Scelle, G. (1920). La loi des huit heures, une évolution remarquable de la technique législative. Revue Politique et Parlementaire, 105, 27-39.

Scelle, G. (1922). Le droit ouvrier. Tableau de la législation française actuelle. Paris: A. Colin.
Scelle, G. (1927). Précis élémentaire de législation industrielle. Paris: Recueil Sirey.

Scharf, F. W. (1998). Interdependence and democratic legitimation (MPIfG Working Paper 98/2). Cologne: Max Planck Institute.

Thuillier, G. (2001). Paul Grunebaum-Ballin et la disparition des grands corps en 1944. La Revue Administrative, 54, 467-472.

Velge, H. (1934). L'évolution juridique de la législation sociale belge. Revue du Travail, 234-247.

Velge, H. (1937). L'organisation des professions est-elle réalisable en Belgique dans le cadre de la constitution? Revue du Travail, 199-207.

Velge, H. (1942). Profession et législation sociale. Bruxelles: Casterman.

Vleeschauwer, R. de (1950). L'organisation professionnelle de l'économie. Paris: Librarie General de Droit et de Jurisprudence.

\section{About the Author}

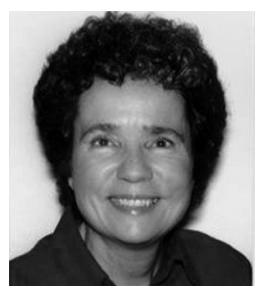

Sabine Rudischhauser, born 1962, studies in history, political science and comparative literature at the universities of Mainz, Dijon, Berlin (FU) and Freiburg. Phil. Diss. 1997. Member of the Centre Marc Bloch Berlin since 2004, scholar at the Université Libre de Bruxelles since 2007, visiting scholar at the Max Planck-Institute for European legal history in Frankfurt a.M. in 2014/15. Research and publications on the history of labour law and the welfare state, especially in France and Germany. 